\title{
Formyl Peptide Chemotaxis Receptors on the Rat Neutrophil: Experimental Evidence for Negative Cooperativity
}

\author{
Wayne A. Marasco, Douglas E. Feltner, and Peter A. Ward \\ Department of Pathology, University of Michigan Medical School, Ann Arbor, Michigan \\ 48109
}

To examine the existence of negative cooperativity among formyl peptide chemo-

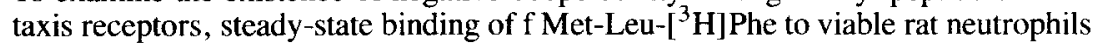
and their purified plasma membranes was measured and the data were subjected to statistical analysis and to computer curve fitting using the NONLIN computer program. Curvilinear, concave upward Scatchard plots were obtained. NONLIN and statistical analyses of the binding data indicated that a two-saturable-sites model was preferable to a one-saturable-site model and statistically valid by the F-test $(\mathbf{P}<.01)$. In addition, Hill coefficients of $0.80 \pm 0.02$ were obtained. Kinetic dissociation experiments using purified plasma membranes showed evidence of site-site interactions of the destabilizing type (negative cooperativity). Thus, unlabeled f Met-Leu-Phe accelerated the dissociation of $\mathrm{f}$ Met-Leu- $\left[{ }^{3} \mathrm{H}\right] \mathrm{Phe}$ under conditions where no rebinding of radioligand occurred. The rate of dissociation of $f$ Met-Leu- $\left[{ }^{3} \mathrm{H}\right]$ Phe from the plasma membranes was dependent on the fold excess of unlabeled $\mathrm{f}$ Met-Leu-Phe used in the dilution medium; at the highest concentration tested (10,000-fold excess), the dissociation rate was more than double the dissociation rate seen with dilution alone. In addition, occupancydependent affinity was ascertained directly by studying the effect of increasing fractional receptor saturation with labeled ligand on the dissociation rate of the receptor-bound labeled ligand. These data showed that the f Met-Leu- $\left[{ }^{3} \mathrm{H}\right] \mathrm{Phe}$ dissociation rate was dependent on the degree of binding site occupancy over the entire biologically relevant range of formyl peptide concentrations. Furthermore, monitoring of the time course of dissociation of the receptor/f Met-Leu- $\left[{ }^{3} \mathrm{H}\right] \mathrm{Phe}$ complex as a function of receptor occupancy revealed that receptor affinity for f Met-Leu-Phe remained occupancy-dependent during the entire time of dissociation examined (up to $10 \mathrm{~min}$ ). Finally, the average affinity profile of the equilibrium binding data demonstrated a $60 \%$ decrease in receptor affinity in changing from the high affinity to the low affinity conformation.

\footnotetext{
Abbreviations used: f Met-Leu-Phe, formyl-methionyl-leucyl-phenylalanine; DMSO, dimethyl sulfoxide; PMSF, phenylmethanesulfonyl fluoride; EDTA, [ethylenedinitrilo] tetraacetic acid; HEPES, N-2hydroxyethylpiperazine- $\mathrm{N}^{\prime}$-2-ethanesulfonic acid; EGTA, [ethylene-bis (oxyethylenitrile)] tetraacetic acid; PBS, phosphate buffered saline; TFA, trifluoroacetic acid.
}

Received March 25, 1984; accepted October 22, 1984.

(C) 1985 Alan R. Liss, Inc. 
Key words: chemotactic receptor, negative cooperativity, chemotaxis

Equilibrium binding of $\mathrm{f}$ Met-Leu- $\left[{ }^{3} \mathrm{H}\right]$ Phe to the formyl peptide chemotaxis receptors on rat neutrophils and their purified plasma membranes generate curvilinear, concave upward Scatchard plots [1]. Such plots are usually ascribed to the presence of multiple classes of independent sites with different but fixed affinities, to the existence of a single class of interacting binding sites with varying affinity depending on occupancy, or to both. However, because equilibrium binding data alone do not distinguish between independent and interacting sites [2,3], evaluation of negative cooperativity has rested on the finding of enhanced dissociation of bound radiolabeled ligand in the presence of an excess of unlabeled ligand which, by increasing occupancy, lowers receptor affinity $[4,5]$.

In this paper, evidence is presented of negative cooperativity among formyl peptide chemotaxis receptors on rat neutrophil plasma membranes. The computer curve fitting program NONLIN was used to substantiate the curvilinearity of the data. This versatile computer program has allowed analysis of the binding data using several mathematical models. Thus, in addition to a one-saturable-site and a twosaturable-sites model used to analyze many hormone-receptor systems, our data was also fit to the Hill equation $[1,6,7]$. Using this approach, NONLIN and statistical analyses of the equilibrium binding data from viable rat neutrophils and their purified plasma membranes indicate that the two-saturable-sites model is preferable to the one-saturable-site model and is statistically valid. However, to establish the existence of negative cooperativity among the formyl peptide chemotaxis receptors, examination was done of the dissociation of $\left.\mathrm{f} \mathrm{Met-Leu-[}{ }^{3} \mathrm{H}\right] \mathrm{Phe}$ from purified neutrophil plasma membranes. These results demonstrated enhanced dissociation of bound tracer in the presence of an excess of unlabeled tracer in the dilution medium; furthermore, the rate of dissociation of bound radiolabeled formyl peptide was dependent on the fold excess of unlabeled formyl peptide used. This finding, which demonstrates sitesite interactions consistent with negative cooperativity, has been reported for insulin $[3,4], \beta$-adrenergic $[8,9]$, leukoagglutinin [5], and certain other hormone-receptor binding systems [reviewed in Ref. 10]. Lastly, our data will show directly an inverse correlation between binding-site occupancy and receptor affinity. These site-site interactions may subsequently regulate the many effector responses that are mediated through this immunologically important receptor.

\section{MATERIALS AND METHODS}

\section{Reagents}

A stock solution of $\mathrm{f}$ Met-Leu-Phe $(10 \mathrm{mM})$ was dissolved in DMSO and the final DMSO concentration in both the dissociation, and the equilibrium binding experiments was always $\leqslant 0.8 \%$. Sodium azide, 2-deoxy-glucose, oyster glycogen (Type II), DMSO, and f Met-Leu-Phe were purchased from Sigma Chemical Co. (St. Louis, MO). Omnifluor, Protosol, and f Met-Leu- $\left[{ }^{3} \mathrm{H}\right] \mathrm{Phe}$ (specific activity 47.6$60.0 \mathrm{Ci} / \mathrm{mmol}$ ) were purchased from New England Nuclear (Boston, MA). Toluene was purchased from Fischer Scientific, Inc. (Pittsburgh, PA). 


\section{Cells}

Retired breeder Sprague-Dawley rats were injected with $60 \mathrm{ml}$ of sterile $1.0 \%$ oyster glycogen in saline and sacrificed $18 \mathrm{hr}$ later with ether [11]. The peritoneal cavities were opened surgically, and the cells were obtained by repeated lavage with Hank's medium containing $10 \mathrm{units} / \mathrm{ml}$ of sodium heparin. Morphologic analysis showed greater than $96 \%$ polymorphonuclear leukocytes as determined by differential Wright's stain. To obtain a sufficient yield of cells for the preparation of plasma membranes, cells from $8-10$ rats were pooled. Cells from three or four rats, elicited with an injection of $60 \mathrm{ml}$ of sterile $0.1 \%$ oyster glycogen in saline, were pooled for use in studies of binding to whole cells.

\section{Preparation of Neutrophil Membranes}

Rat neutrophil plasma membranes were prepared as follows: $2.5-5.0 \times 10^{9}$ cells were washed twice in Hank's medium, resuspended to $50 \mathrm{ml}$ in $11.6 \%$ sucrose (10 mM HEPES, $1 \mathrm{mM}$ EDTA, $10 \mu \mathrm{M}$ PMSF), swollen at $37^{\circ} \mathrm{C}$ for $15 \mathrm{~min}$, and centrifuged at $500 \mathrm{~g}$ for $5 \mathrm{~min}$. Resuspension, swelling and centrifugation were repeated until the swollen cell pellet had approximately doubled in volume. The swollen cells were resuspended to $7.5 \mathrm{ml}$ in the $11.6 \%(\mathrm{w} / \mathrm{v})$ sucrose solution, homogenized (twice) for $3 \mathrm{~min}$ with a tissue homogenizer (Fischer Scientific, Inc. Dyna-Mix model, setting 6) and centrifuged at $1000 \mathrm{~g}$. The resulting low-speed supernatant and cell pellet were separately layered onto discontinuous sucrose gradients constructed from $10.8 \mathrm{ml} 50 \%$ sucrose, $8.4 \mathrm{ml} 40 \%$ sucrose, and $10.8 \mathrm{ml} 30 \%$ sucrose. All sucrose solutions contained $10 \mathrm{mM}$ HEPES, $1 \mathrm{mM}$ EGTA, and $10 \mu \mathrm{M}$ PMSF (pH 7.0-7.2). The crude membranes were centrifuged at $120,000 \mathrm{~g}$ for $90 \mathrm{~min}$ at $4^{\circ} \mathrm{C}$ (Beckman L5-65B Ultracentrifuge, SW28 rotor). Membrane proteins from the $11.6 \%$ to $30 \%$ (Band 1), $30 \%$ to $40 \%$ (Band 2), and $40 \%$ to $50 \%$ (Band 3) sucrose interfaces were collected separately, diluted in phosphate buffered saline (PBS) (2.14 $\mathrm{nM} \mathrm{NaH} 2 \mathrm{PO}_{4} \mathrm{H}_{2} \mathrm{O} ; 9.15 \mathrm{mN} \mathrm{Na} \mathrm{HPO}_{4} ; 268 \mathrm{mM} \mathrm{NaCl}$ ), and pelleted by centrifugation at $10,000 \mathrm{~g}$ at $4^{\circ} \mathrm{C}$ overnight. Band 1 and Band 2 pellets were resuspended to a final volume of $1 \mathrm{ml}$ each, whereas the Band 3 pellet was resuspended to $2 \mathrm{ml}$. No detectable lysozyme (specific granule) or $\mathrm{N}$-acetyl-glucosaminidase (azurophil granule) activity was found in the Band 2 preparations used in most of the present studies. In addition, the Band 2 preparations were found to be ten-fold enriched in $\mathrm{f} \mathrm{Met-Leu-}$ $\left[{ }^{3} \mathrm{H}\right] \mathrm{Phe}$ binding activity on the protein basis as compared to whole cells (data not shown). Furthermore, electron microscopic analysis of these plasma membranes (Band 2) demonstrated the presence of very few electron dense granules in the preparation. Protein concentration was determined with a Bio-rad protein assay kit [12], using bovine serum albumin as the standard.

\section{High-Performance Liquid Chromatography of $\mathrm{M}$ Met-Leu- $\left[{ }^{3} \mathrm{H}\right] \mathrm{Phe}$}

To insure that impurities were not present in the commercially available f MetLeu- $\left[{ }^{3} \mathrm{H}\right]$ Phe we used, the product was analyzed for purity as previously described [13]. In brief, the liquid chromatography system consisted of a Varian LC-5020 and Varichrom, variable wavelength detector. The sample was run through a reverse phase, $\mathrm{C}_{18}, 5 \mu \mathrm{m}$ (MCH5) particle size column (Varian Instruments). Chromatography was run under the following conditions: flow rate $1.0 \mathrm{~mL} / \mathrm{min}$, temperature $30^{\circ} \mathrm{C}$, gradient elution over $60 \mathrm{~min}$ from $20 \%$ to $45 \% \mathrm{CH}_{3} \mathrm{CN}$ in $\mathrm{H}_{2} \mathrm{O}$ containing 
$0.1 \%$ TFA throughout, and column pressure that never exceeded 250 atmospheres. Spectrophotometric detection was set at $210 \mathrm{~nm}$. Under these conditions, f Met-Leu$\left[{ }^{3} \mathrm{H}\right] \mathrm{Phe}$ appeared as a single peak at $45 \mathrm{~min}$, corresponding exactly to the retention time of unlabeled $f$ Met-Leu-Phe. When required, one-minute fractions were collected, thoroughly dried in a Speed Vac (Savant Instruments) rotary evaporator, resuspended to the original volume in ethanol, and assayed for binding activity.

\section{Measurement of $f$ Met-Leu- $\left[{ }^{3} \mathrm{H}\right]$ Phe Binding}

Binding of $\mathrm{f}$ Met-Leu- $\left[{ }^{3} \mathrm{H}\right] \mathrm{Phe}$ to purified rat neutrophil plasma membranes (Band 2) was measured at $4^{\circ} \mathrm{C}$ using the silicone oil centrifugation assay of Mackin et al [14] with several modifications. Specifically, $50 \mu \mathrm{l}$ of $600 \mu \mathrm{g} / \mathrm{ml}$ solution of Band 2 membrane in phosphate buffered saline was gently layered onto $75 \mu \mathrm{l}$ of a mixture (151:49) of F50 and F96 silicone fluids (General Electric, Silicone Products Department, Waterford, NY) in a $500 \mu \mathrm{l}$ plastic microcentrifuge tube (Walter Sarstedt, Inc., Princeton, NJ). The F50 and F96 oils were mixed to attain a density $\left(1.030 \mathrm{gm} / \mathrm{cm}^{3}\right)$ that would allow the membranes to pellet. Five microliters of an appropriate dilution $(0.1 \mathrm{nM}$ to $80 \mathrm{nM}$ final concentration) of labeled peptide were then added to the membranes. A single concentration $\left(8 \times 10^{-5} \mathrm{M}\right.$, final concentration) of unlabeled $\mathrm{f}$ Met-Leu-Phe was used to determine nonspecific binding. This provided a 1,000-fold or greater excess of unlabeled peptide at all concentrations of $\mathrm{f}$ Met-Leu- $\left[{ }^{3} \mathrm{H}\right] \mathrm{Phe}$. The membranes then were incubated for $30 \mathrm{~min}$ at $4{ }^{\circ} \mathrm{C}$, conditions found to be sufficient to establish equilibrium. After incubation, the tubes were centrifuged for $2 \mathrm{~min}$ in an Eppendorf Microcentrifuge (Brinkmann Model S412). After aspiration of the liquid phase, the bottom of the microfuge tube was cut off and the membrane pellet was solubilized with $0.75 \mathrm{ml}$ of a $1: 1$ Protosol:toluene mixture. The scintillation vials were capped, vortexed, and allowed to sit overnight at room temperature. After $18 \mathrm{hr}, 5.0 \mathrm{ml}$ of scintillation fluid (Omnifluor, $16 \mathrm{gm} / \mathrm{l}$, in toluene) were added, the tubes again vortexed and their radioactivity determined. Nonspecific binding was generally $10-20 \%$ of total binding. Data points were determined in duplicate and averaged.

f Met-Leu- $\left[{ }^{3} \mathrm{H}\right]$ Phe binding to whole rat neutrophils also was measured; 2.0 $2.5 \times 10^{6}$ rat neutrophils in $0.1 \mathrm{ml} \mathrm{Hank}$ 's buffer plus $1.6 \mathrm{mM} \mathrm{Ca}^{++}$were layered onto $0.5 \mathrm{ml}$ of SF1250 silicone fluid (density $\left.=1.05 \mathrm{~g} / \mathrm{cm}^{3}\right)($ General Electric, Silicone Products Department, Waterford, NY) contained in a $1.5 \mathrm{ml}$ plastic microcentrifuge tube. Also, $10 \mathrm{mM}$ 2-deoxyglucose and $10 \mathrm{mM}$ sodium azide were included in the incubating buffer to minimize internalization of the labeled peptide [11]. Bound radioactivity was quantitated and analyzed as described for membranes. Data points were determined in triplicate.

\section{Analysis of Binding Data}

The binding data were analyzed using NONLIN, a weighted nonlinear least squares regression analysis computer program [6,7]. Nonspecific binding was first subtracted from total binding either as individual points or as a parameter. Similar results were obtained using both methods. The binding data were fit to one or more of the appropriate equations for a one-saturable-site model, a two-saturable-sites model, and the Hill equation [7]. Initial estimates of apparent dissociation constants $\left(\mathrm{K}_{\mathrm{D}}\right)$ and binding capacities $(\mathrm{nM})$ for use with the NONLIN program were determined by linear regression analysis of data plotted according to the method of Scatchard [15]. An initial estimate of 0.75 was used for the Hill coefficient when fitting data to 
the Hill equation. When a good fit was obtained, higher and lower values $(0.5$ and 1.0) were tested to assure that convergence had not occurred upon a local minimum [16]. The weighting factor, $1 / y_{\text {obs }}$, was selected only after determining that the variance was a linear function of the dose of $\mathrm{f} \mathrm{Met-Leu-}\left[{ }^{3} \mathrm{H}\right] \mathrm{Phe}$ added to the reaction [17]. The weighted sums of squared deviations (WSSDs) generated by NONLIN for one saturable site, two saturable sites, and the Hill equation were compared using the F-test [16]. In addition, the data were subjected to a Runs test $[18,19]$ to demonstrate further the goodness of fit to the theoretical curve.

\section{Measurement of $\mathrm{f}$ Met-Leu- $\left[{ }^{3} \mathrm{H}\right]$ Phe Dissociation}

Neutrophil membranes (Band 2) $(400-500 \mu \mathrm{g} / \mathrm{ml}$ in PBS) were incubated at $4^{\circ} \mathrm{C}$ in siliconized $16 \times 125 \mathrm{~mm}$ glass test tubes in a total volume of $105 \mu \mathrm{l}$ and with a low concentration of $\mathrm{f} \mathrm{Met-Leu}-\left[{ }^{3} \mathrm{H}\right] \mathrm{Phe}(4.0 \mathrm{nM})$ so that only a small fraction of receptor sites were occupied by the tracer [11]. After $30 \mathrm{~min}$, when steady-state binding was achieved, the membranes were diluted to $10 \mathrm{ml}$ with either PBS $\left(4^{\circ} \mathrm{C}\right)$ or PBS plus various concentrations of unlabeled f Met-Leu- $\left[{ }^{3} \mathrm{H}\right] \mathrm{Phe}\left(4.0 \times 10^{-7}-4.0\right.$ $\times 10^{-5} \mathrm{M}: 100-10,000$-fold excess). In some studies, viable rat neutrophils were used under the same conditions except that the cells were suspended and dissociated in Hank's buffer plus calcium. Bound f Met-Leu- $\left[{ }^{3} \mathrm{H}\right]$ Phe was measured after $0,1,2,5$, and $10 \mathrm{~min}$ of dissociation by a glass fiber vacuum filtration method [20] and quantified by liquid scintillation counting. All data points were determined in triplicate, and the standard error of the mean was consistently less than $10 \%$. The theoretical basis of this experimental design was initially described by De Meyts et al $[4,10]$. In the system described here, negative cooperative interactions are detected by studying the dissociation of a tracer amount of $\mathrm{f}$ Met-Leu- $\left[{ }^{3} \mathrm{H}\right]$ Phe from the formyl peptide receptors under two conditions: at an "infinite" dilution of the peptidereceptor complex and at an "infinite" dilution of the complex in the same medium containing an excess of unlabeled peptide. If site-site interactions of a destabilizing type are induced by peptide binding (negative cooperativity), unlabeled peptide filling empty receptors sites will accelerate the dissociation of the labeled peptide bound to other receptor sites [10]. Conversely, in the absence of site-site interactions, unlabeled peptide binding to free sites will not affect the dissociation rate of $\mathrm{f} \mathrm{Met}-\mathrm{Leu}-\left[{ }^{3} \mathrm{H}\right] \mathrm{Phe}$ from filled sites.

Negative cooperative interactions also were tested for directly by incubating membranes (Band 3) with increasing concentrations of $\mathrm{f} \mathrm{Met-Leu-}\left[{ }^{3} \mathrm{H}\right] \mathrm{Phe}(4.0-100$ $\mathrm{nM}$ ) and then measuring the rates of tracer dissociation as a function of receptor occupancy. After reaching equilibrium, bound f Met-Leu- $\left[{ }^{3} \mathrm{H}\right] \mathrm{Phe}$ was measured after $0,1,2,5$, and $10 \mathrm{~min}$ of dissociation (as above) and expressed as a fraction of $\mathrm{f}$ Met-Leu- $\left[{ }^{3} \mathrm{H}\right]$ Phe bound at $0 \mathrm{~min}$ (initial time of dilution). Dissociation rates then were calculated by linear regression for the first $2 \mathrm{~min}$ of dissociation (see Results); typically, the correlation coefficients were $\geqslant 0.95$.

Two controls with viable cells were run to demonstrate the lack of significant rebinding of $\mathrm{f} \mathrm{Met-Leu-}\left[{ }^{3} \mathrm{H}\right]$ Phe from bulk solution [3]. In the first, the same dilution scheme for dissociation was used (as above), and a comparison of dilution alone and dilution plus unlabeled $\mathrm{f}$ Met-Leu- $\left[{ }^{3} \mathrm{H}\right] \mathrm{Phe}$ over a wide range of concentrations was made. The results indicated that the difference between the two conditions was constant at a 30 -fold or greater dilution. Thus, the 100-fold dilution that we routinely used approximates an infinite dilution. 
In the second control, an additional $100 \mu \mathrm{l}$ aliquot of cells $\left(2.5 \times 10^{7} / \mathrm{ml}\right)$ not previously exposed to labeled or unlabeled $\mathrm{f}$ Met-Leu-Phe was injected into a reaction tube containing the same number of cells immediately after dilution with either Hank's or Hank's plus unlabeled f Met-Leu-Phe. Dissociation was allowed to continue for 10 min before cell-bound radioactivity was measured. A lack of rebinding was observed since it was found that the amount of binding in the presence and absence of an additional aliquot of fresh cells was, within experimental error, identical.

\section{RESULTS}

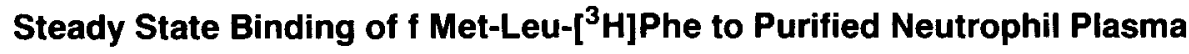 Membranes}

Binding of $\mathrm{f}$ Met-Leu- $\left[{ }^{3} \mathrm{H}\right] \mathrm{Phe}$ to neutrophil plasma membranes was performed under equilibrium conditions at $4^{\circ} \mathrm{C}$ using a silicone oil centrifugation assay and computer modeling of the binding data were performed. Figure 1 represents a typical binding isotherm. NONLIN and statistical analysis of the binding data indicated that

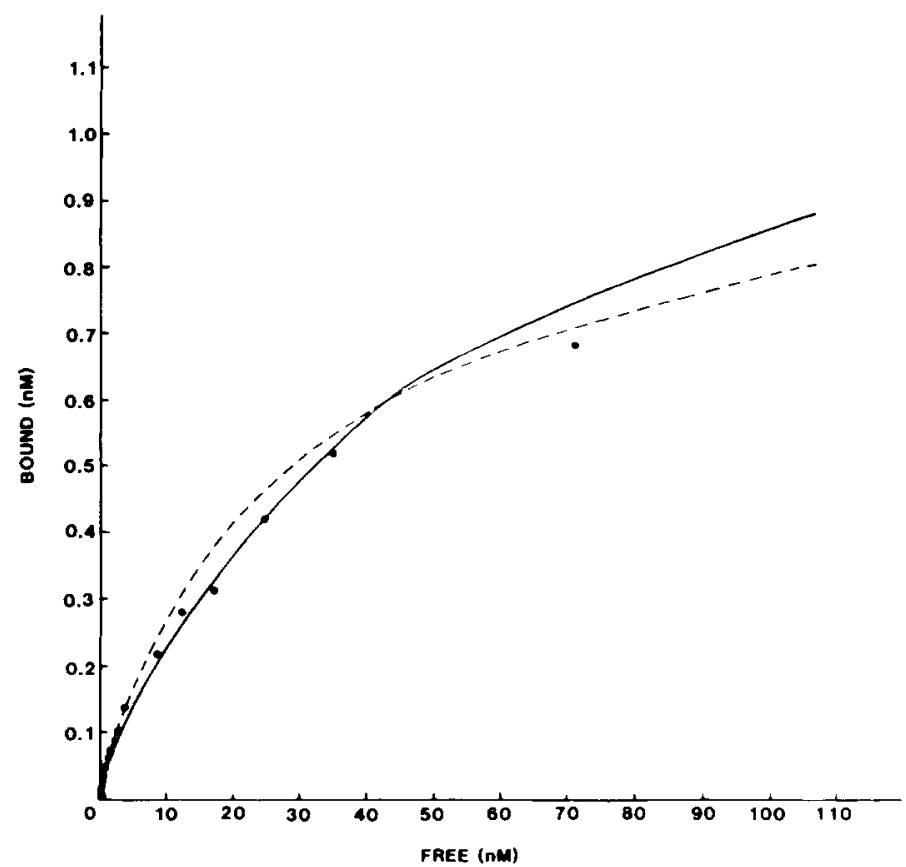

Fig. 1. Binding isotherm of specific f Met-Leu- $\left[{ }^{3} \mathrm{H}\right]$ Phe bound to Band 2 neutrophil plasma membranes $(30 \mu \mathrm{g})$. The data were corrected for nonspecific binding and analyzed with NONLIN $(1,6,7)$. The hatched line represents a one site fit to the data, and the solid line represents a two site fit to the same data. The data points of specific f Met-Leu- $\left[{ }^{3} \mathrm{H}\right]$ Phe binding also are shown ( $O$ ) and represent the mean of duplicate determinations. The standard errors of the mean were less than $10 \%$. The fit derived from the two-site-model was significantly better $(\mathrm{P}<.01)$ than that derived from the one site model. The characteristics of the different models for this representative experiment were: one-site-model, $\mathrm{K}_{\mathrm{D}}=29.18 \pm 1.64 \mathrm{nM}$ and $1.85 \pm 0.07 \mathrm{pmol} / \mathrm{mg}$ binding capacity; two site model, a high affinity site $\mathrm{K}_{\mathrm{DH}}=1.35 \pm 0.25 \mathrm{nM}$ and a low affinity site $\mathrm{K}_{\mathrm{DL}}=62.95 \pm 7.51 \mathrm{nM}$. Of the two sites detected, $4.5 \%$ were of the higher affinity $(0.11 \pm 0.01 \mathrm{pmol} / \mathrm{mg})$ and $95.5 \%$ were of the lower affinity $(2.37 \pm 0.18 \mathrm{pmol} / \mathrm{mg})$; for the Hill equation, Hill coefficient of $0.80 \pm 0.02$ was obtained. 
the two-saturable-sites model was preferable to the one-saturable-site model $(\mathrm{P}<.01)$. The assumption of additional parameters reduced the weighted sums of squared deviations sufficiently to justify the more complex model. In addition, the curvilinear model passed the Runs test $[18,19]$. Scatchard analysis of this same data was curvilinear as expected (data not shown). A composite summary of the analysis of the binding models from two separate experiments are shown in Table I. The characteristics of the two-saturable-sites model were a high affinity site with a $\mathrm{K}_{\mathrm{D}}$ value of $1.25 \pm 0.10 \mathrm{nM}$ and a low affinity site with a $K_{D}$ value of $43.64 \pm 19.32$ $\mathrm{nM}$. Three percent of the sites detected were of the higher affinity. In addition, this same data when applied to the Hill equation were characterized by a Hill coefficient of $0.86 \pm 0.06$.

\section{Steady State Binding of $f$ Met-Leu- $\left[{ }^{3} \mathrm{H}\right]$ Phe to Viable Neutrophils}

Binding studies of $\mathrm{f}$ Met-Leu- $\left[{ }^{3} \mathrm{H}\right]$ Phe to viable neutrophils also were performed; Figure 2 represents a typical binding isotherm. NONLIN and statistical analysis of the binding data again indicated that the two-saturable-sites model was preferable to the one-saturable-site model $(\mathrm{P}<.01)$. NONLIN and statistical analysis of composite data from five separate experiments, each with a curvilinear Scatchard plot, are shown in Table II. The characteristics of the two-sites-model were a high affinity site with a $K_{D}$ value of $0.86 \pm 0.20 \mathrm{nM}$ and a low affinity site with a $\mathrm{K}_{\mathrm{D}}$ value of $54.78 \pm 9.81 \mathrm{nM}$. Of the two sites detected, $8 \%$ were of the higher affinity. These values ranged, in five individual experiments, from 5 to $25 \%$ for the high affinity sites. The same data, when applied to the Hill equation, were characterized by a Hill coefficient of $0.77 \pm 0.05$.

\section{Kinetic Analysis of $\mathrm{f}$ Met-Leu-[ $\left.{ }^{3} \mathrm{H}\right]$ Phe Dissociation from Plasma Membranes: Evidence for Negative Cooperativity}

Because steady-state binding alone can be fitted by both the two saturable sites model and the negative cooperativity model, studies of the kinetics of dissociation of

TABLE I. Analysis of Steady State Binding of $\mathrm{f}$ Met-Leu- $\left[{ }^{3} \mathrm{H}\right]$ Phe Binding to Rat Neutrophil Plasma Membranes

\begin{tabular}{|c|c|c|c|}
\hline \multirow[b]{2}{*}{ Binding parameters } & \multicolumn{2}{|c|}{ Binding site models ${ }^{a}$} & \multirow[b]{2}{*}{ Hill equation } \\
\hline & 1 Saturable site & 2 Saturable sites & \\
\hline $\mathrm{K}_{\mathrm{D} 1}(\mathbf{n M})$ & $24.61 \pm 4.57$ & $1.25 \pm 0.096$ & $27.78 \pm 7.73^{\mathrm{b}}$ \\
\hline Binding capacities (pmol/mg) & $4.18 \pm 2.33$ & $0.143 \pm 0.033$ & $5.03 \pm 2.09$ \\
\hline $\mathbf{K}_{\mathrm{D} 2}(\mathbf{n M})$ & NA & $43.64 \pm 19.32$ & NA \\
\hline Binding capacities (pmol/mg) & NA & $4.50 \pm 2.13$ & NA \\
\hline Significance $^{c}$ & NA & $\mathrm{P}<0.001$ & $\mathrm{P}<0.001$ \\
\hline Hill coefficient & NA & NA & $0.86 \pm 0.06$ \\
\hline
\end{tabular}

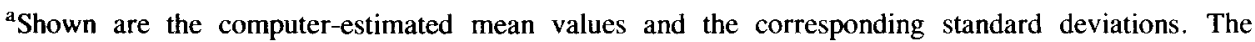
estimation was based on the mean of two individual experiments each of which contained 1419 data points each performed in duplicate.

${ }^{b}$ For the Hill equation, the equation for the computer modeling $[1,7]$ can be simplified such that at half saturation, $K_{D}=[L]^{n} H$ where $[L]$ equals the molar concentration of free $f$ Met-Leu- $\left[{ }^{3} H\right] P h e$ and ${ }^{n} H$ equals the Hill coefficient. Therefore, we report the $\mathrm{K}_{\mathrm{D}}$ at half saturation raised to the Hill coefficient. ${ }^{\mathrm{c}}$ Significance, indicated by results of F-ratio tests, pertains to the statistical difference of the data relative to those for the model with one saturable site.

NA - not applicable. 


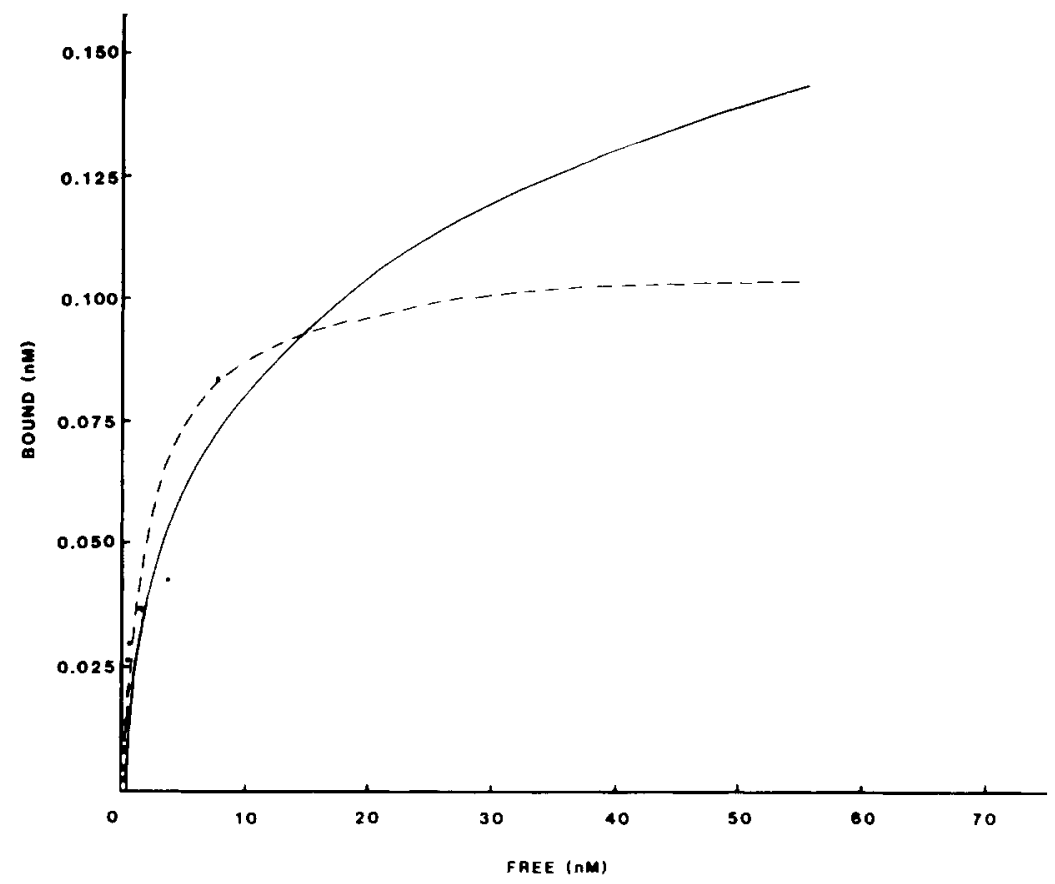

Fig. 2. Binding isotherm of specific f Met-Leu- $\left[^{3} \mathrm{H}\right] \mathrm{Phe}$ bound to viable neutrophils $\left(2.5 \times 10^{6}\right.$ cells $)$. The data was corrected for nonspecific binding and analyzed with NONLIN $[1,6,7]$. The data points of specific binding (O) are the mean of triplicate determinations with SEM less than $10 \%$. The hatched line represents a one site fit to the data, and the solid line represents a two site fit to the same data. The fit derived from the two site model was significantly better $(\mathrm{P}<.01)$ than that derived from the onesite model. The characteristics of the different models for this representative experiment were: one site model, $\mathrm{K}_{\mathrm{D}}=2.38 \pm 0.17 \mathrm{nM}$ and $2,764 \pm 147$ sites/cell: two-site model, a high-affinity site $\mathrm{K}_{\mathrm{DH}}=0.94 \pm 0.40 \mathrm{nM}$ and a low affinity site $\mathrm{K}_{\mathrm{DL}}=25.28 \pm 7.92 \mathrm{nM}$. Of the two sites detected, $25 \%$ were of the higher affinity $(1,219 \pm 235$ sites/cell), and $75 \%$ were of the lower affinity $(3,505 \pm 934$ sites/cell); for the Hill equation, Hill coefficient of $0.72 \pm 0.07$ was obtained.

TABLE II. Analysis of Steady State Binding of f Met-Leu- $\left[{ }^{3} \mathrm{H}\right]$ Phe to Viable Rat Neutrophils

\begin{tabular}{lccc}
\hline & \multicolumn{2}{c}{ Binding site models $\mathrm{s}^{\mathrm{a}}$} & \\
\cline { 2 - 3 } Binding parameters & \multicolumn{1}{c}{ 1 saturable site } & 2 saturable sites & Hill equation \\
\hline $\mathrm{K}_{\mathrm{D} 1}(\mathrm{nM})$ & $9.93 \pm 0.30$ & $0.867 \pm 0.20$ & $10.738 \pm 0.33^{\mathrm{b}}$ \\
Sites/cell & $4,123 \pm 99$ & $599 \pm 58$ & $5,350 \pm 37$ \\
$\mathrm{~K}_{\mathrm{D} 2}(\mathrm{nM})$ & $\mathrm{NA}$ & $54.78 \pm 9.81$ & $\mathrm{NA}$ \\
Sites/cell & $\mathrm{NA}$ & $7,030 \pm 836$ & $\mathrm{NA}$ \\
Significance $^{\mathrm{c}}$ & $\mathrm{NA}$ & $\mathrm{P}<.01$ & $\mathrm{P}<.01$ \\
Hill Coefficient & $\mathrm{NA}$ & $\mathrm{NA}$ & $0.77 \pm 0.05$ \\
\hline
\end{tabular}

aShown are the computer-estimated mean values and the corresponding standard deviations. The estimation was based on 100 data points obtained in five separate experiments each with a curvilinear Scatchard plot.

${ }^{b}$ See Table I for explanation.

${ }^{\text {c}}$ Significance, indicated by results of F-ratio tests, pertains to the statistical difference of the data relative to those for the model with one saturable site.

NA - Not applicable. 
the f Met-Leu- $\left[{ }^{3} \mathrm{H}\right]$ Phe-receptor complex were used to differentiate between the two models $[4,10]$. As can be seen in Figure 3, when various excess concentrations of unlabeled $\mathrm{f}$ Met-Leu-Phe were included in the dilution medium, an increase in both the rate and extent of $\mathrm{f} \mathrm{Met-Leu-}\left[{ }^{3} \mathrm{H}\right]$ Phe dissociation was observed. Because the dissociation appeared to be heterogeneous, only the first 2 min of dissociation, which approximated a linear function, were used to calculate the dissociation rates. Table III shows that the increased dissociation rate was dependent upon the concentration of $f$ Met-Leu-Phe included in the dilution medium and at the highest concentration of f Met-Leu-Phe tested (10,000-fold excess), the dissociation rate was more than double the dissociation rate seen with dilution alone. Similar results were obtained with viable rat neutrophils (data not shown).

\section{Effect of Increasing Receptor Occupancy at Equilibrium on $f$ Met-Leu- $\left[{ }^{3} \mathrm{H}\right]$ Phe Dissociation from Plasma Membranes}

The effect of varying the degree of receptor occupancy at equilibrium with f Met-Leu- $\left[{ }^{3} \mathrm{H}\right]$ Phe on the subsequent dissociation rate of $\left.\mathrm{f} \mathrm{Met-Leu-[}{ }^{3} \mathrm{H}\right]$ Phe was

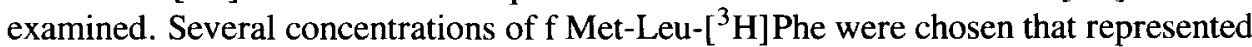
different levels of receptor occupancy as determined from the binding isotherm (Fig. 1). After reaching equilibrium, the reaction mixtures were infinitely diluted, bound $f$ Met-Leu- $\left[{ }^{3} \mathrm{H}\right]$ Phe was measured, and the dissociation rates were calculated. Table IV shows that as receptor occupancy was increased from a small percentage of filled sites (4 $\mathrm{nM}$ f Met-Leu- $\left[{ }^{3} \mathrm{H}\right] \mathrm{Phe}$ ) to a large percentage of filled sites (100 nM f MetLeu- $\left.\left[{ }^{3} \mathrm{H}\right] \mathrm{Phe}\right)$, the receptor affinity decreased as evidenced by an increase in the dissociation rate. This increase (over the rates determined at $4 \mathrm{nM} \mathrm{f}$ Met-Leu$\left.\left[{ }^{3} \mathrm{H}\right] \mathrm{Phe}\right)$ ranged for several experiments from $36 \%$ to $70 \%$. Furthermore, the fractional percentage of initially bound tracer that remained bound at each time point examined was proportionally decreased as the initial incubating concentration of f Met-Leu- $\left[{ }^{3} \mathrm{H}\right]$ Phe was progressively increased (ie, increased receptor occupancy). Thus, these data directly show an inverse correlation between binding-site occupancy and affinity, which is consistent with the existence of negative cooperativity.

\section{DISCUSSION}

The interactions of $\mathrm{f}$ Met-Leu- $\left[{ }^{3} \mathrm{H}\right] \mathrm{Phe}$ with rat neutrophils and their purified plasma membranes generate curvilinear, concave upward Scatchard plots [1]. Such plots are consistent with heterogeneous binding sites with different but fixed affinities or with interacting sites resulting in negative cooperativity $[2,4]$. However, because steady state binding data alone do not discriminate between these models, other approaches must be used to delineate between these different possibilities. Several of the possible artifactual causes of concave curvilinearity of the Scatchard plots have been analyzed and found to be unlikely. Among these are: 1) Failure of the ligandreceptor interaction to reach equilibrium at all concentrations of ligand. In initial experiments using various concentrations of labeled peptide, it was demonstrated that binding equilibrium was reached over a broad concentration range using the binding conditions that we report (data not shown); 2) Binding of flexible ligands [21]: This possibility is eliminated because it is known from NMR studies that $\mathrm{f}$ Met-Leu-Phe maintains a rigid anti-parallel $\beta$-pleated sheet conformation in solution [22]. 3) The presence of several different radioactive ligands in the binding medium, with corre- 


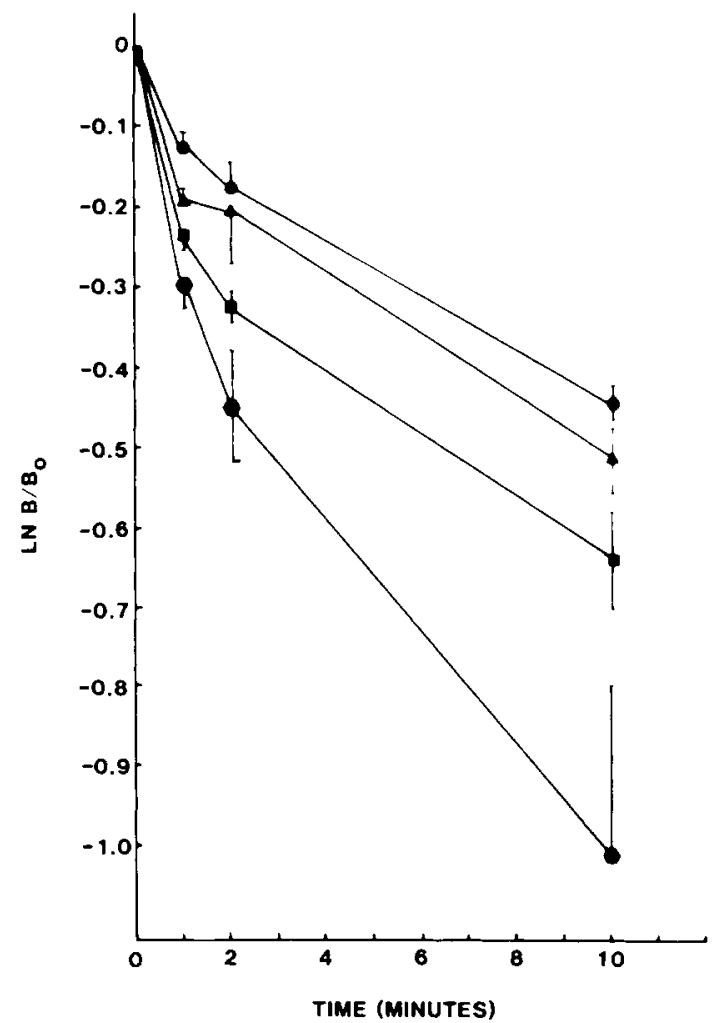

Fig. 3. Dissociation of $\mathrm{f} \mathrm{Met-Leu-}{ }^{3} \mathrm{H} \mid \mathrm{Phe}$ bound to neutrophil plasma membranes. Membranes were incubated at $4{ }^{\circ} \mathrm{C}$ with $4 \mathrm{nM}$ f Met-Leu- $\left[{ }^{3} \mathrm{H}\right] \mathrm{Phe}$ in a $100 \mu \mathrm{l}$ volume. After $30 \mathrm{~min}$, the membranes were diluted to $10 \mathrm{ml}$ with either PBS buffer $(-\infty)$ ) or PBS buffer plus a 100 -fold $(\mathbf{\Delta}-\mathbf{\Delta}), 1,000$ fold ( $-\mathbf{a}$ ), or 10,000-fold ( was measured after $0,1,2$, and $10 \mathrm{~min}$ of dissociation by a glass fiber vacuum filtration method [20]. The radioactivity bound to the cells (expressed as the natural log of the fraction bound at time (t) after dissociation was initiated divided by the amount bound at the initial time of dilution, $t=0$ ) is plotted as the time elapsed after dilution of the system. The figure represents pooled data from three separate experiments. Error bars \pm SEM.

sponding different affinities for the receptors, a possibility that has been eliminated also by the analysis of $\mathrm{f}$ Met-Leu- $\left[{ }^{3} \mathrm{H}\right]$ Phe purity by HPLC (see Methods).

One approach used to discriminate between these two curvilinear models is based on the theoretical considerations put forth by De Meyts et al $[3,4]$ that filling empty receptor sites with unlabeled peptide increases the dissociation of labeled peptide from other sites only when site-site interactions of the negative cooperative type are present. By this criteria, it has been shown in the present study with neutrophil plasma membranes that an increase in the dissociation rate of cell bound $f$ Met-Leu- $\left[{ }^{3} \mathrm{H}\right]$ Phe is seen when increasing concentrations of unlabeled $\mathrm{f}$ Met-Leu-Phe are included in the dilution buffer. These results parallel results originally obtained for the insulin receptor $[3,4]$ and in a number of other receptor systems [5, 8-10, 23]. This phenomenon is thus widespread, although not universal [10]. However, the validity of the data initially generated in the insulin-lymphocyte system recently has 
TABLE III. Effect of $f$ Met-Leu-Phe Molar Excess on the Rate of Dissociation of $f$ Met-Leu- $\left[{ }^{3} \mathrm{H}\right]$ Phe from Neutrophil Plasma Membranes*

\begin{tabular}{lcc}
\hline $\begin{array}{l}\text { Dilution } \\
\text { buffer }\end{array}$ & $\begin{array}{c}\text { Dissociation rate } \\
\left(10^{-3} \mathrm{sec}^{-1}\right)\end{array}$ & $\begin{array}{c}\text { \% Increase in } \\
\text { dissociation rate } \\
\text { over dilution alone }\end{array}$ \\
\hline PBS & $1.61 \pm 0.30^{\mathrm{c}}$ & - \\
$100^{\mathrm{b}}$ & $2.28 \pm 0.56$ & 41.6 \\
1,000 & $2.72 \pm 0.16$ & 68.9 \\
10,000 & $3.74 \pm 0.61$ & 132 \\
\hline
\end{tabular}

*f Met-Leu- $\left[{ }^{3} \mathrm{H}\right]$ Phe (4.0 nM) was incubated with Band 2 neutrophil plasma membranes $(40 \mu \mathrm{g})$ for $30 \mathrm{~min}$ at $4^{\circ} \mathrm{C}$. The reaction mixture was then diluted to $10 \mathrm{ml}$ with either PBS buffer or PBS plus various concentrations of unlabeled $f$ Met-Leu-Phe, and the remaining bound radioactivity was determined at regular intervals $(0,1,2$, and $10 \mathrm{~min})$ by rapid filtration.

${ }^{a}$ Dissociation rates were calculated by linear regression for the first 2 min of dissociation.

${ }^{b}$ Number indicates fold excess of unlabeled $\mathrm{f}$ Met-Leu-Phe in dilution buffer.

${ }^{c}$ Mean \pm SEM (three experiments).

been questioned on various grounds, including the observation of similar interactions in a non-receptor system [24] and because enhanced dissociation of bound labeled insulin in the presence of unlabeled insulin appeared to be independent of binding-site occupancy [25]. Furthermore, despite its widespread use in the evaluation of negative cooperativity, other interpretations of the enhancement of the dissociation rate of bound labeled hormone by unlabeled hormone in the dilution medium have been reported [26,27]. For example, alternative models based on the formation of a ternary complex involving the interaction of the receptor $(R)$ with an additional membrane component $(\mathrm{X})$ leading to the agonist $(\mathrm{H})$-promoted formation of a high-affinity ternary complex (HRX) have been proposed [27-30] to explain the kinetics of enhanced dissociation in the presence of unlabeled ligand. However, the existence of such effector molecules and the formation of a formyl peptide receptor-ternary complex have not been determined. Thus, although the curvilinear concave upward Scatchard plot, together with the enhanced dissociation in the presence of unlabeled ligand (due to site-site interactions), has been widely accepted as evidence of negative cooperativity, it is possible that in certain receptor systems and under specific conditions other mechanisms may be involved.

A second and widely accepted approach to identify negative cooperativity among receptor sites is to analyze directly occupancy-dependent affinity. This can be accomplished by studying the effect of increasing fractional receptor saturation with labeled ligand on the dissociation rate of the receptor-bound ligand [3,5]. In this paper, it has been shown that the f Met-Leu- $\left[{ }^{3} \mathrm{H}\right]$ Phe dissociation rate from neutrophil membranes was dependent on the degree of binding site occupancy over the entire biologically relevant range of formyl peptide concentrations. Furthermore, monitoring of the time course of dissociation of the receptor/f Met-Leu- $\left[{ }^{3} \mathrm{H}\right]$ Phe complex as a function of receptor occupancy revealed that receptor affinity for $f$ Met-Leu$\left[{ }^{3} \mathrm{H}\right] \mathrm{Phe}$ remained occupancy-dependent during the entire time of dissociation exam- 
TABLE IV. Effect of Varying Initial Receptor Occupancy With $f$ Met-Leu-[ $\left[{ }^{3} \mathrm{H}\right]$ Phe on the Rate of $f$ Met-Leu- $\left[{ }^{3} \mathrm{H}\right]$ Phe Dissociation from Neutrophil Plasma Membranes*

\begin{tabular}{cc}
$\begin{array}{c}\text { f Met-Leu- }\left[{ }^{3} \mathrm{H}\right] \text { Phe concen- } \\
\text { tration used to vary receptor } \\
\text { occupancy }(\mathrm{nM})\end{array}$ & $\begin{array}{c}\text { Enhancement of } \\
\mathrm{f} \text { Met-Leu- }-\left[{ }^{3} \mathrm{H}\right] \text { Phe dissociation } \\
\text { rate }^{\mathrm{a}}(\% \text { of maximal })\end{array}$ \\
\hline 4 & - \\
10 & 39 \\
40 & 81 \\
100 & 100 \\
\hline
\end{tabular}

*Triplicate $16 \times 125 \mathrm{~mm}$ siliconized glass test tubes containing $40 \mu \mathrm{g}$ neutrophil plasma membranes (Band 3 ) were incubated for $30 \mathrm{~min}$ at $4^{\circ} \mathrm{C}$ with increasing concentrations of $\mathrm{f}$ Met-Leu- $\left[{ }^{3} \mathrm{H}\right)$ Phe $(105 \mu 1$ final volume). After reaching equilibrium, the membranes were diluted to $10 \mathrm{ml}$ with PBS buffer and bound $\mathrm{f} \mathrm{Met-Leu-}\left[{ }^{3} \mathrm{H}\right] \mathrm{Phe}$ was measured after $0,1,2,5$ and $10 \mathrm{~min}$ of dissociation and expressed as the fraction of $f$ Met-Leu- $\left[{ }^{3} \mathrm{H}\right]$ Phe bound at $0 \mathrm{~min}$ (initial time of dilution). Dissociation rates were then calculated by linear regression for the first 2 min of dissociation.

${ }^{a}$ The $\mathrm{f}$ Met-Leu- $\left[{ }^{3} \mathrm{H}\right] \mathrm{Ph}$ dissociation rate was enhanced $65 \%$ (mean of 3 experiments) at $100 \mathrm{nM} f$ Met-Leu- $\left[{ }^{3} \mathrm{H}\right] \mathrm{Phe}$ (dissociation rate $=1.28 \pm 0.09 \times 10^{-3} \mathrm{sec}^{-1}$ ) compared to $4 \mathrm{nM} \mathrm{f} \mathrm{Met-Leu-}$ $\left[^{3} \mathrm{H}\right] \mathrm{Phe}\left(7.74 \pm 1.16 \times 10^{-4} \mathrm{sec}^{-1}\right)$ and the values listed are expressed as a percentage of that maximal enhancement.

ined (up to $10 \mathrm{~min}$ ). Thus, our results are in agreement with other receptor systems describing negative cooperativity including the insulin-lymphocyte [3], thrombinplatelet [31] and leukoagglutinin-lymphocyte [5] systems in which accelerated ligand dissociation was shown to be dependent on the level of occupancy before dissociation.

Computer modeling in many hormone-receptor systems is utilized to substantiate the curvilinearity of the binding data. In most cases, a one-saturable-site model is compared to a two-saturable-sites model when comparing the degree of fit. Indeed, this has been the case for the laboratories reporting curvilinearity of the Scatchard plots with the formyl peptide receptor system $[14,32,33]$. In this report, the versatile computer curve fitting program NONLIN was used to analyze our curvilinear binding data using similar mathematical models. The curvilinearity of the equilibrium binding data, together with the Hill coefficients $<0.85$ [34] and the change in receptor affinity with increased receptor occupancy, favors a simple receptor model that assumes the existence of a homogenous class of binding sites that undergo site-site interactions at all levels of occupancy. In addition, the interactions increase when receptor occupancy increases. However, it is possible that other, more complex binding isotherms also may fit the data. Among such examples would be multiple classes of interacting binding sites or a single homogenous class of binding sites that undergo site-site interactions within only certain ranges of receptor occupancy.

With regard to the latter possibility, De Meyts and Roth [35] have designed a simple graphical presentation of steady state binding data to measure the continually changing "average" affinity of the receptors in a cooperative system. This plot also permits assessment of both the fractional occupancy of receptors required to initiate cooperative interactions and the occupancy above which increased saturation creates no further alteration in receptor affinity $[9,35]$. Assuming that when binding sites are 
unoccupied and the receptors are all in the same conformation and have an identical affinity for the ligand, one can calculate an average affinity or association constant $(\overline{\mathrm{K}})$ at each level of receptor occupancy. When these calculations are made from steady state data for the binding of $\mathrm{f}$ Met-Leu- $\left[{ }^{3} \mathrm{H}\right]$ Phe to neutrophil membranes (Fig. 4A) or viable neutrophils (Fig. 4B), it can be seen that changes in receptor affinity occur with occupancy of as few of $1 \%$ of the formyl peptide receptors. Thus, negative cooperative interactions among formyl peptide receptors appear to be very sensitive to low levels of ligand. Furthermore, because neither a limiting high affinity nor a limiting low affinity plateau is seen at any fractional level of receptor occupancy, it would appear that the binding data can be modeled to a homogenous class of binding sites that undergo site-site interactions at all levels of occupancy. In addition, if one examines the affinities at the lowest and highest fractional percent occupancies achieved in the representative membrane experiment (Fig. 4A), there is a $60 \%$ decrease in affinity in going from the high affinity to the low affinity state. This value is in close agreement to the decrease in affinity found in the occupancy-dependent affinity experiments (Table IV).

Several investigators have presented evidence that $\mathrm{f}$ Met-Leu- $\left[{ }^{3} \mathrm{H}\right] \mathrm{Phe}$ binds to a heterogenous population of receptors on viable rabbit [14] and human [33] neutrophils and their plasma membranes [14,32]. Curvilinear Scatchard plots and Hill coefficients $<1.0$ have been observed and quantitative analysis of the binding using a "multiple classes of sites" model has been extensively described. However, a negative cooperative model has not been considered. With rabbit neutrophils, the reversibility of binding data demonstrated similar off rates in Hank's medium and Hank's plus a 100-fold excess of unlabeled peptide suggesting that the binding was not cooperative [36]. Although this discrepancy may reflect important species differences (as has been found in other receptor systems [9]), it is also possible that other factors play an important role. For example, a l0-fold more rapid dissociation rate is found with the rabbit neutrophil [37] as compared to the rat neutrophil [11]. This would make negative-cooperative interactions more difficult to detect experimentally in the rabbit. With human neutrophils, increasing the receptor occupancy did not affect the rate of dissociation of the peptide-receptor complex thus making negative cooperativity an unlikely explanation for the complex binding isotherms [32]. However, these dissociation kinetics did agree with the two affinity model. More recently, these authors have presented membrane binding data that indicate that the two classes of binding sites are composed, at least in part, of interconvertible states of one population of receptors [38]. Seligmann et al [39] have presented biological evidence to support further the curvilinear binding model. They have shown, by measuring membrane fluorescence changes, that human peripheral blood neutrophils undergo a reversible $f$ Met-Leu-Phe induced shift in response $K_{m}$ (the concentration of $f$ MetLeu-Phe producing a half-maximal response) to higher values after a short preexposure to $\mathrm{f}$ Met-Leu-Phe. These authors believe that such behavioral adaptation, which may occur as a result of modulation of receptor affinity, is consistent with either functional negative cooperative interactions and/or heterogeneity of formyl peptide receptors, ie, f Met-Leu-Phe induced expression of lower affinity receptors on the plasma membrane.

Although both the dissociation studies and occupancy-dependent affinity studies demonstrate that the formyl peptide receptor on rat neutrophil membranes undergo ligand-induced changes in conformation, they do not allow, without additional exper- 

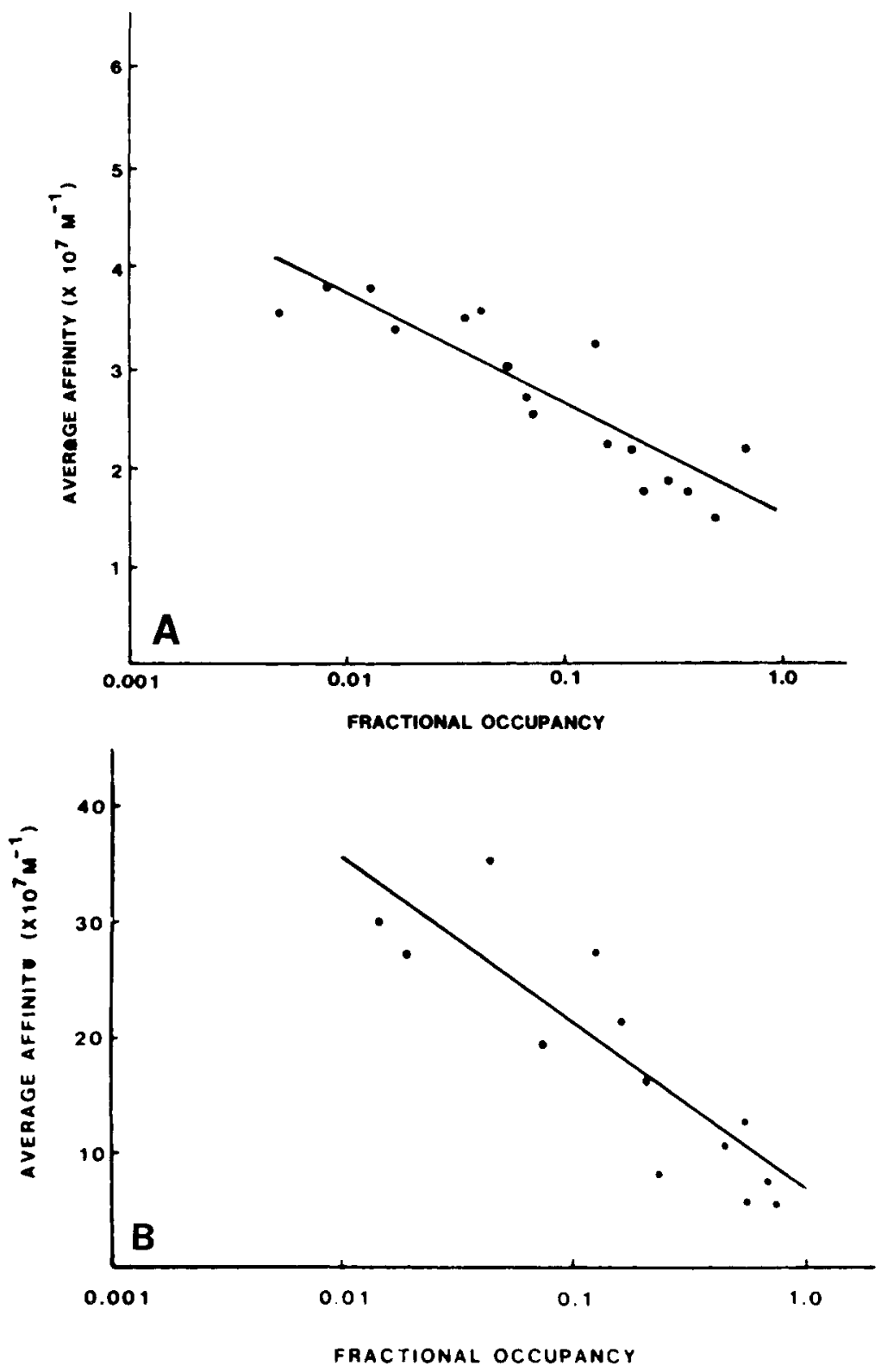

Fig. 4A. Average affinity profile of the membrane binding data from Figure $1 . \bar{K}$, the average affinity, calculated as $(B / F) /\left(R^{\circ}-B\right)$, is plotted as a function of $\log \bar{Y}=\log \left(B / R^{\circ}\right)$, where $\bar{Y}=$ fractional occupancy, Bound (B) and Free (F) keep their same meaning and $R^{\prime \prime}=$ the abscissa intercept. Note that limiting high and low affinities have not been reached (plateaus at either extreme do not occur).

Fig. 4B. Average affinity profile of the f Met-Leu- $\left[{ }^{3} \mathrm{H}\right]$ Phe binding data to viable neutrophils shown in Figure 2. Note that limiting high and low affinities have not been reached (plateaus at either extreme do not occur). 
imentation, a description of the precise molecular mechanism involved. It is possible that cooperative interactions among formyl peptide receptors are a function of both the receptor molecule itself and the membrane matrix with which it is associated. In this regard, several specific possibilities exist, including 1) a change in the conformations of receptors that can exist in the membrane in oligomeric form; the nature of the site transition from one state to another could be, by analogy with known cooperative phenonoma in other macromolecules [40-43], due to a change in the tertiary and/or quaternary receptor configurations; 2) agonist-induced cross-linking of initially noninteracting receptors consistent with both the observations made by Niedel et al [44] that clusters of receptors are formed after a short incubation with a fluorescinated formyl peptide analogue and observations made by Walter and Marasco [45] that occupied receptors move to the anterior end of the cell following a short incubation with $\mathrm{I}^{125}$-formyl peptide; 3 ), a model in which a cooperative membrane response can be generated by a cluster of oligomeric receptors has been described $[46,47]$. Furthermore, a combination of the possibilities mentioned above ( 1 and 2) could exist where conformational changes in individual oligomeric receptors are propagated further in other receptors when clustering occurs $[3,46]$; and [4], liberation of an "effector" from a dissociating receptor which would mediate the site-site interactions [3,29].

Although the physiologic role of negative cooperativity among formyl peptide receptor sites on neutrophils is still speculative, this phenomenon may provide for greater sensitivity to low concentrations of the bacterial chemo-attractants $[13,48,49]$ and/or the selective modulation of biologic responses at different concentrations of the formyl peptides. Chemotaxis, which occurs in the presence of relatively low levels of attractant, requires only a small proportion of receptors to be occupied to induce a maximal chemotactic response [11,50-55]. Upon arriving at the site of infection (high levels of bacterial attractant), the neutrophil phagocytizes the bacteria, such behavior involving the secretion of lysosomal enzymes and production of superoxide anion $\left(\mathrm{O}_{2}{ }^{-}\right)$. This is consistent with the properties of the receptor since the $\mathrm{ED}_{50} \mathrm{~s}$ for superoxide production and for lysosomal enzyme release are both greater than that for chemotaxis $[11,52-54]$. Thus, the formyl peptide receptor may be an example of a single homogenous class of receptors that can modulate different cellular activities as a function of the degree of receptor occupancy.

\section{ACKNOWLEDGMENTS}

These studies were supported in part by NIH grants HL-26498 and HL-28422. We would like to acknowledge Dr. Steven V. Fischel (Department of Neuroscience, Harvard Medical School) and Dr. Fedor Medzikradsky (Department of Biological Chemistry, University of Michigan Medical School) for their assistance with the NONLIN program, Dr. Sem Phan (Department of Pathology, University of Michigan Medical School) for his help in analyzing the purity of $f$ Met-Leu- $\left[{ }^{3} \mathrm{H}\right]$ Phe by HPLC, and Robin Kunkel for her assistance with the electron microscopy of the rat plasma membranes. We would also like to thank Jeny Breakstone for her excellent secretarial assistance in the preparation of this manuscript. 


\section{REFERENCES}

1. Marasco WA, Feltner DE. Ward PA: J Cell Biochem Suppl 8A:27, 1984.

2. Rodbard D: Adv Exp Med Biol 36:289, 1973.

3. DeMeyts P, Bianco AR, Roth J: J Biol Chem 251:1877, 1976.

4. DeMeyts P, Roth J, Neville Jr, DM, Gavin III, JR, Lesniak MA: Biochem Biophys Res Commun $55: 154,1973$.

5. Faguet GB: Am J Physiol 237:E207, 1979.

6. Metzler CM, Elfring GL, McEwen AJ: Biometrics 30:526, 1974.

7. Fischel SV, Medzihradsky F: Mol Pharmacol 20:269, 1981.

8. Limbird LE, DeMeyts P, Lefkowitz RJ: Biochem Biophys Res Commun 64:1160, 1975.

9. Limbird LE, Lefkowitz RJ: J Biol Chem 251:5007, 1976.

10. DeMeyts P: J Supramol Struct 4:241, 1976.

11. Marasco WA, Fantone JC, Freer RJ, Ward PA: Am J Pathol 111:273, 1983.

12. Bio-Rad Protein Assay Instruction Manual. Bulletin 78:0791. Bio-Rad Laboratories, January 1979.

13. Marasco WA, Phan SH, Krutzsch H. Showell HJ, Feltner DE, Nairn R, Becker EL, Ward PA: J Biol Chem 259:5430, 1984.

14. Mackin WM, Huang C, Becker EL: J Immunol 129:1608, 1982.

15. Scatchard G: Ann NY Acad Sci 51:660, 1949.

16. Boxenbaum HG, Riegelman S, Elashoff RM: J Pharmacokinet Biopharmacol 2: 123, 1974.

17. Finney DJ, Phillips P: Appl Statist 26:312, 1977.

18. Freund JE: “Mathematical Statistics," Ed. 2. Englewood Cliffs: Prentice-Hall, Inc., 1971 p. 352.

19. Beyer WH: "Handbook of tables for Probability and Statistics." Cleveland: The Chemical Rubber Co., 1966 p. 317.

20. Marasco WA, Showell HJ, Becker EL: Biochem Biophys Res Commun 99:1065, 1981.

21. Laiken N. Nemethy G: Biochemistry 10:2101, 1971.

22. Becker EL, Bleich HE, Day AR, Freer RJ. Glasel JA. Visintainer J: Biochemistry 18:4656. 1979.

23. Frazier WA, Boyd LF, Bradshaw RA: J Biol Chem 249:5513, 1974.

24. Cuatrecasas P, Hollenberg MD: Biochem Biophys Res Commun 62:31. 1975.

25. Pollet RJ. Stangert ML. Haase BA: J Biol Chem 252:5828, 1977.

26. DeLean A, Rodbard D: Fed Proc 39:116, 1980.

27. Jacobs S, Cuatrecasas P: Biochim Biophys Acta 433:428, 1976.

28. DeHaen C: J Theor Biol 58:383, 1976.

29. Boeynaems JM, Dumont JE: J Cyclic Nucleotide Res 1:123, 1975.

30. DeLean A, Stadel JM, Lefkowitz RJ: J Biol Chem 255:7108, 1980.

31. Tollefsen DM, Majerus PW: Biochemistry 15:2144, 1976.

32. Koo C, Lefkowitz RJ, Snyderman R: Biochem Biophys Res Commun 106:442, 1982.

33. Mehta J, Spilberg I: Inflammation 7:301, 1983.

34. Levitzki A, Koshland Jr DE: Proc Natl Acad Sci USA 62:1121, 1969.

35. DeMeyts P, Roth J: Biochem Biophys Res Commun 66:1118, 1975.

36. Zigmond SH, Sullivan SJ: J Cell Biol 82:517, 1979.

37. Sullivan SJ, Zigmond SH: J Cell Biol 85:703, 1980.

38. Koo C, Lefkowitz RJ, Snyderman R: I Clin Invest 72:748, 1983.

39. Seligmann BE, Fletcher MP, Gallin JI: J Biol Chem 257:6280, 1982

40. Monod J, Wyman J, Changeux JP: J Mol Biol 12:88, 1965.

41. Koshland DE Jr, Nemethy G, Filmer D: Biochemistry 5:365, 1966.

42. Rubin MM, Changeux JP: J Mol Biol 21:265. 1966.

43. Hertzfeld J, Stanley HE: J Mol Biol 83:231, 1974.

44. Niedel JE, Kahane I, Cuatrecasas P: Science 205:1412, 1979.

45. Walter RJ, Marasco WA: Exp Cell Res 154:613, 1984.

46. Levitzki A: J Theor Biol 44:367, 1974.

47. Levitzki A, Segel LA, Steer ML: J Mol Biol 91:125, 1975.

48. Schiffmann E, Showell HJ, Corcoran BA. Ward PA, Smith E, Becker EL: J Immunology 114:1831, 1975.

49. Marasco WA, ShowelI HJ, Freer RJ, Becker EL: J Immunology 128:956, 1982. 
50. Aswanikumar S, Corcoran B, Schiffman E, Day AR, Freer RJ, Showell HJ, Becker EL, Pert CB: Biochem Biophys Res Commun 74:810, 1977.

51. Williams LT, Snyderman R, Pike MC, Lefkowitz RJ: Proc Natl Acad Sci USA 74:1204, 1977.

52. Showell HJ, Freer RJ, Zigmond SH, Schiffman E, Aswanikumar S, Corcoran BA, Becker EL: J Exp Med 143:1154, 1976.

53. Freer RJ, Day AR, Schiffman E, Aswanikumar S, Showell HJ, Becker EL: Biochemistry 19:2404, 1980.

54. Freer RJ, Day AR, Muthukumaraswamy N, Pinon D, Wu A, Showell HJ, Becker EL: Biochemistry $21: 257,1982$.

55. Schiffmann E, Aswanikumar S, Venkatasubramanian K, Corcoran BA, Pert CB, Brown J, Gross E, Day AR, Freer RJ, Showell HJ, Becker EL: FEBS Lett 117:1, 1980. 